\title{
Weber's theory of domination and post-communist capitalisms
}

\author{
Iván Szelenyi ${ }^{1}$
}

Published online: 9 December 2015

(C) The Author(s) 2015. This article is published with open access at Springerlink.com

\begin{abstract}
This article has four main objectives. First, it introduces the ideal types of domination of Weber. Contrary to the received wisdom, which knows only "three ideal types" (traditional, charismatic and legal rational) I present the "fourth" type of domination, Weber called "Wille der Beherrschten" as an important correction of his ideal type of legal-rational authority. Next I make a novel, critical distinction between patrimonial and prebendal types of traditional authority. Third, I discuss various ways that communist regimes tried to legitimate themselves and how they entered eventually a legitimation crisis, leading to the collapse of communism. In the next section, I explore the different ways post-communist capitalisms seek legitimacy (with various combinations of legal rational authority and patrimonialism), and finally I conclude with a trend of re-convergence of some post-communist systems (especially Russia and Hungary, but with signs for similar trends elsewhere) into an illiberal, prebendal quasi-democratic system.
\end{abstract}

Keywords Ideal types of domination - Legitimate authority ·

Post-communist capitalisms · Max Weber - Liberalism · Democratic system · Capitalisms

\section{Introductory notes on Weber's theory of power, domination, and legitimacy}

The main purpose of this article is to explore whether post-communist capitalism, at least some versions of it, can be regarded as legitimate authority. The nature of political regimes of certain post-communist regimes, especially the rule by Presidents Putin and $\mathrm{Xi}$ and since 2010 that of Hungarian Prime

Iván Szelenyi

ivan.szelenyi@nyu.edu

1 Balzac u. 35, V.2, 1136 Budapest, Hungary 
Minister Orbán's government, is often hotly debated, nevertheless the question whether these regimes are legitimate at all and if so on what ground do they claim legitimacy is rarely posed. ${ }^{1}$

When a system can be called "legitimate" can be debated and the answers to these questions depend to a large extent on our definition of terms. The aim of my article is rather limited. My point of departure is Max Weber's theory of legitimacy and the only question I pose is: Were communist and are post-communist regimes of Putin, Xi, or Orbán legitimate in terms of Weber's theory, and if they are, what are the bases of their claim for legitimacy? Weber's distinction between power (Macht) and domination/authority (Herrschaft) is crucial to answer this question. The dispute how to translate Herrschaft into English is indicative of the controversy about some of the issues of legitimacy. Talcott Parsons offered one of the first-at that time still incomplete - translations of Economy and Society into English. He translated Herrschaft in a very American way as "authority." ${ }^{2}$ The term-which is occasionally also used by Weber-implying the respectability of those who issue commands, rather than emphasizing the asymmetry of power relationships between those who dominate and those who are subordinated to domination. ${ }^{3}$ Gerth and Mills just about the same time (Parson was a political conservative, while Mills was on the political left, and Gerth as a native German speaker had an arguably deeper understanding of what "Herrschaft" meant) both translated Herrschaft as "domination." Whether Herrschaft means authority or domination is of some importance to understanding Weber's work and especially the theory of legitimation. ${ }^{5}$ Weber himself was hesitant in his terminology. In the earlier drafts of Economy and Society, he used the term "authority" quite often, but as he was redrafting the work for what was eventually published as chapters 1-4 in the version of the book edited by Marianna Weber (Weber 1978), in the

\footnotetext{
${ }^{1}$ There is a gigantic literature on this matter, mainly debating whether countries like Russia, Belarus, and Hungary still can be called democracy, or did they turn into "managed democracy" (P. Anderson 2007) or are they already "autocracies" (Kormai 2014), "illiberal democracies" (Zakaria 1997). Some even call those regimes neo-fascist or neo-communist. Nevertheless, the question of legitimacy is relatively rarely posed, which may have a lot to do with the absence of analytical clarity of the concept of legitimacy. After Putin's election to the presidency in 2012, Russian journalists suggested Putin is "illegitimate" (Russian journalists 2012). The former liberal mayor of Budapest, Gábor Demszky, called the Orbán regime illegitimate (See Rádai Eszter 2014). There are also some attempts though to see new types of legitimacy emerging in post-communist "managed democracies" or "autocracies." Daniel Bell saw Confucianism as a new legitimating principle of post-Maoist China (Bell 2008), Ossinovski, in an intriguing MSc dissertation, sees Putin's Russia as a combination of charismatic and legal-rational authority (Ossinovski 2010)

2 Astonishingly, Parsons does not translate the term "Herrschaft" even ONCE as "domination." He is in pain when he has to translate "Herrschaft" from the German original- see $M W G$, Band 23, 2013, p. 210-where Herrschaft is so obviously not simply authority - a respectable exercise of power - so he invents the difficult concept,"imperative control" (Weber 1947, p. 152). This notion captures the tone of the concept better than authority, but still misses the idea of "subordination" found in "domination."

${ }^{3}$ Max Weber, The Theory of Social and Economic Organization, 1947.

${ }^{4}$ Gerth and Mills, from Max Weber, (1946).

${ }^{5}$ The question how to translate Herrschaft into English has been debated for some time. Mommsen (1974, p. 74) among others pointed out the difficulties of translation, but in the end he also concluded domination is the most appropriate term.
} 
chapters written sometimes between 1919 and 1920, while the earlier versions were written in 1914 or before, ${ }^{6}$ suddenly the word authority almost completely disappears and Herrschaft is used almost exclusively. ${ }^{7}$

In order to understand why this is important we need to go back to the distinction between Macht and Herrschaft. In the later work (1919-1920) Weber defines clearly the difference between the two forms of exercising influence on others. As he puts it so eloquently in the last version of the book: power (Macht) is the probability that one actor within the social relationship will be in a position to carry out his own will despite resistance (Weber 2013 Band 23, p. 210). ${ }^{8}$ Weber now has a clear definition of Herrschaft as well: "Domination (Herrschaft) is the probability that a command ... will be obeyed." This is about as clear as it can get. Hence Macht (power) + legitimacy = Herrschaft (domination).

Weber's theory of domination assumes that those subjected to domination do have some degree of "belief" in the system. Those who obey order do so-at least to some extent- "voluntarily." No system of domination can sustain itself if it is just driven by customs, personal advantage or even effectual or idealistic attachment by those subordinated to authority:

... [E]very genuine form of domination implies a minimum of voluntary compliance, that is, an interest ... in obedience... [C] ustoms, personal advantage, purely effectual or ideal motives of solidarity do not form a sufficiently reliable basis for a given domination. In addition there is ..... a further element, the belief in legitimacy.... [E]very system attempts to establish ... the belief in its legitimacy (Weber 1978, pp. 212-213).

Many important questions stem from this definition. For me, the crucial question is how to interpret the notion of belief. What kind of, how strong a belief of those subordinated to authority need there be in order to acknowledge domination as legitimate, and who should hold such "beliefs"?

In order to appreciate Weber's sophistication, one has to understand his claim that the privileged groups are not actually "superior." They merely base their claim for obedience in the myth of their superiority. In Weber's words: "Every highly privileged group develops a myth of its ... superiority. Under the conditions of stable distribution of power that myth is accepted by the negatively privileged strata" (p. 953).

Hence those who obey orders typically suspect those who dominate justify their superiority by a "myth," therefore their belief is likely to be rather "passive." In other words, the "masses" (my term, not Weber's) are unlikely to have a positive, or affirmative belief in their masters, rulers, leaders, or bosses. They will believe that

\footnotetext{
${ }^{6}$ Edith Hanke is uncertain how to date the first formulation, but believes it has to be dated before WWI, $M W G$, Vol. 22-4, 2005, p.118.

${ }^{7}$ Contrast $M W G$, Band 22-4, Teilband 4 (written in 1914 or before) and $M W G$, Band 23 (written in 1919/1920) where the term authority hardly appears. When in the first published version of Economy and Society he defined Herrschaft he put behind the term Herrschaft in brackets and quotation marks "authority" this way: Herrschaft (“Autorität”), see Weber 1978, Vol. I. p.212 or MWG 2013, Band 23, p. 449.

${ }^{8}$ Already in the draft he wrote before the war, Weber tried to emphasize that Herrschaft implies obedience to command: " $\ldots$ in our terminology domination shall be identical with authoritarian power of command" (Weber 1978, p. 946; Weber 2005, p, 135)
} 
the domination imposed on them is justified since at this point in time they cannot find a realistic alternative. I do not have to love my master, king, husband, prime minister, CEO, Dean, department chair, or whatever: that person will exercise authority as long as I believe this person is better than any of his or her alternatives. If the masses begin to consider a possible alternative ruler/master the system is facing only a "legitimation problem."

Arguably that is a different story for the "staff." In every complex society domination is exercised through a staff and unlike ordinary people (or the masses) the staff is supposed to have a positive, affirmative belief in the myths that justify/legitimate authority. If the staff loses its positive belief in the myth of domination the legitimacy of the system may be in a crisis.

The Shah of Iran was never particularly loved by the people of Iran. They eventually began to hear the message of Khomeini from radical Islamic preachers during the Friday sermons and many Iranians might have believed this to be a better alternative to the rule of the Shah. That created a legitimation problem. But the Shan only fell, when his security apparatus abandoned him. As his staff lost faith in him the legitimation problem turned into a legitimation crisis.

But the road from legitimation problem to legitimation crisis and eventual collapse of the regime is certainly not a one-way street. Most Western liberal capitalist societies faced during the 1960s a serious legitimation problem. As student movements — on rare occasions with some support from labor-began to formulate an alternative to liberal democratic capitalism hence the system faced a legitimation problem-especially around 1968 - but history teaches us liberal capitalism has an extraordinary capacity to survive, not only economically, but also ideologically. Capitalist systems often incorporate "subversive ideologies" into its own world view (for instance, affirmative action for minorities and women and gay rights, which appeared irreconcilable with the world views of liberal capitalism, the "bourgeois social order" before the 1960s are reasonably acceptable now for the middle classes).

As I pointed out before the relationship between "staff" and "ruler" (by ruler I simply mean that person/office that issues command to be obeyed), is quite critical for Weber' theory of history. As history unfolds or "develops"9 the relationship between the "ruler" and the "staff" changes. Indeed in the most elementary form of social organization (still existent in the family), namely under patriarchal authority the "ruler" has no "staff." In more complex forms, let's call it prebendalism - though Weber' terminology is not carved into stone - the staff has only rather limited claims to appropriate the means of administration (and property). Those are at the discretion of the ruler. In contrast under patrimonialism at least some of the means of administration (and let's foreshadow some of the property rights) are appropriated (though with some limitations) by the staff. In what he calls bureaucratic or legal rational authority no individual (neither the person in authority nor his/her staff) has the rights of coercion, coercive rights are the monopoly of the state (but let us add: the private property rights of all individuals and incumbency of office are secure). I elaborate more about this later in this article.

\footnotetext{
${ }^{9}$ Roth and Schluchter suggests that Weber has no theory of "evolution," he rather conceived "development" over time, see Roth and Schluchter 1979, pp. 195-206; Schluchter 1981, pp. 1-5.
} 
It is crucial to see: for Weber's interpretative sociology the purpose of the concept of legitimacy is to interpret the various ways domination was operating over human history, to write a genealogy of human history. Much like with the theory of rationality Weber resisted the idea to call a certain type of human action "rational" and others as "irrational". Nothing could have been further from Weber than to limit the uses of legitimate order only to social organization that had existed only during the past hundreds or 200 years, hence was "legitimated" by the rule of law or had majoritarian approval, and to designate the rest of human history as "illegitimate." In Weber's theory "irrational" action and "illegitimate" social order were marginal or exceptional cases. The good question was not to ask: is this action rational, or is this social order legitimate, but rather to explore what is the rationality of this action, what is the ground of legitimacy of this order.

Let me try to give examples of illegitimate rule. Illegitimate rule for Weber means the unsustainable system where those in command can obtain compliance only by systematic and actual use of coercion. I put the term "actual" in bold because East European dissidents in the 1980 - who wanted to question the legitimacy of late communist regimes - suggested they are illegitimate since they promise coercion in cases of non-compliance though do not exercise such coercion. In my view this would be unacceptable for Weber. All systems of domination promise coercion: even in a democratically constituted legal-rational authority those who do not comply with the rules/laws will be coerced. In many-if not most - countries people can even be executed. The modern state merely "monopolizes" the power of coercion, but it can never abandon it. Hence a system is illegitimate when those in command have to rely actually on massive coercion, like the mid-to-late 1930 Gulag in the USSR and the Nazi network of concentration camp during the war, arguably even the Kádár regime between 1957 and 1963, with several hundred political prisoners being executed and thousands imprisoned or deported. In an illegitimate system those who issue commands use Macht, they are unable to sustain or have lost Herrschaft, hence voluntary compliance by those subjected to their command.

In his work on legitimacy Weber also writes about "non-legitimate" types of actions/ systems, which is critically different from "illegitimate rule." If I may use here the Gramscian terminology, "non-legitimate authority" is similar to an emerging "counter-hegemony."

The prime example of non-legitimate authority is the Western city. Interestingly enough in the German original - posthumously published text - Weber did not use the term "non-legitimate authority" (Weber 1999, Band 22-5, p. 59). I assume the term non-legitimate domination was added as a subtitle for Chapter XVI "The City" (Weber 1978 , p. 1212) by Marianna Weber, who edited the whole work for publication. Nevertheless the term "non-legitimate authority" (following the logic of non-rational as distinct from irrational) is a sensible one. What is the bottom line in the manuscript Die Stadt? My short take on this is: the city that emerges in the West has one exceptional feature: it is an island in the ocean of traditional authority, which introduces a new principle, the principle of Jus soli by offering Bürgertum, or "citizenship" (and freedom from the master) for all those who spent a certain amount of time in the city. It introduces a new principle of legitimacy - territoriality - that is not accepted as legitimate in the surrounding ocean of traditional authority where everyone's identity is decided by Jus sanguinis, by ancestry. "Stadfluft macht frei" (the city air makes you 
free) is the "non-legitimate" principle of the Western city not known in other cities of history (Weber 1999, Band 22-5: 105). If a serf spent a relatively short period of time in the city and swore allegiance to the city, he became its "Bürger," or "citizen" and his master could not reclaim him or her any longer. Non-legitimate authority implies an embryo that begins to grow within the wombs of a previous system of domination. It is not legitimate yet, but has a reasonable chance to become legitimate. No determination is implied: non-legitimate authority does not necessarily become legitimate: members of communes of the 1960 might have believed the way they live-which might have involved promiscuity - could eventually become the norm, would become the legitimate way to live. It did not happen-so far-but that does not mean it was not a potentiality.

Let's summarize what we have said so far: systems are legitimate if those subordinated to authority accept their subordination, since they cannot define a better alternative and the staff of the person who issues commands has a firm belief that the master's claims (myths for his superiority) are valid. Those systems are illegitimate that have to coerce the ones subjected to authority to obey orders; hence they have to jail, kill, and torture masses of people in a rather unpredictable way to obtain obedience. Illegitimate authority is unlikely to sustain itself in the long run. Legitimate order always assumes some degree (even if a weak one) of belief and voluntariness. People obey orders from an illegitimate authority merely if they are afraid of what will happen to them if they do not comply; they are concerned about their life and livelihood.

\section{The three (and the fourth) ideal types of legitimate authority}

Weber makes distinction between three "ideal types of dominations/authority": traditional, charismatic and legal/rational. Nevertheless, in a lecture delivered in Vienna in the fall of 1917 he considered a fourth possible type of authority, and I will briefly deliberate on this. ${ }^{10}$ The distinction between the initial three types serves dual purposes: 1) it is part of his philosophy of history. To put it brutally simple: history develops from earlier stages. It is not "evolution," since a) it is not inevitable, societies can be "stuck" at earlier phases of "development," and b) an interpretative social scientist has no way to claim that later phases are superior to earlier stages. In addition 2) while the typology is mainly historical it is also "trans-organizational." Every actually existing society can be interpreted as a mix of the three types of domination. All actually existing systems have some elements from all three — and as I try to show: indeed four-ideal types. We may live in a legal-rational social order, but occasionally political leaders may have charismatic appeal and in the family — or in our universities - we may be subjected to patriarchal authority, while fundamentally universities are governed by laws and rules. And to continue with the fourth type of authority: we may live in a legal-rational order where the executive is not in its place by the will of those subordinated to authority (this is the case for instance when a king rules in a constitutional monarchy) or those who exercise political authority may have majoritarian approval but may violate the principles of the rule of law (think of Vladimir Putin).

\footnotetext{
${ }^{10}$ See the review of his lecture in October 25, 1917 in Neue Freie Press, reproduced in Weber 2005, Band 22-4, pp. 752-756).
} 


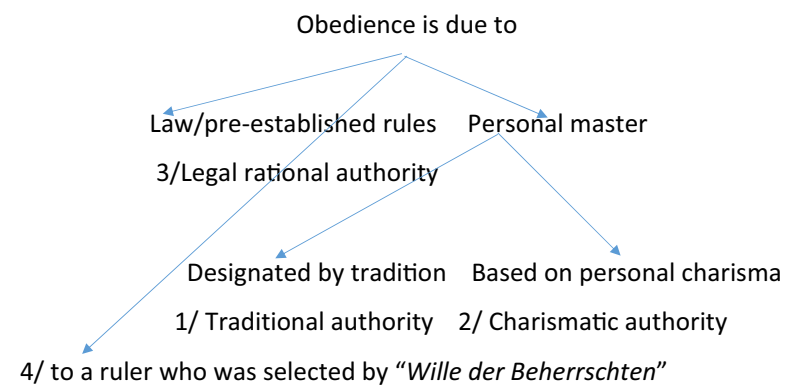

Fig. 1 Obedience and four types of authority

This is very much the essence of the Weberian approach. Our task is to explore the nature of legitimacy in any society: to what extent is a society governed by legal-rational authority? Are there some elements of charismatic or traditional authority present in this social system? It is never either/or, the right question is: what is the empirical mix in any particular concrete empirical case.

First, let me briefly review the three ideal types Weber presents to us in Economy and Society and amend it with the "fourth type" at the end of this section of the article. In this article my main task is to explore what is the mix we can find in a communist and post-communist society and how different it is from other societies we are familiar with. The basis of this classification is to whom obedience is due on what grounds in the various systems of domination.

It is important to note that the ontological status of the four types of authority is not quite the same (see Fig. 1). While traditional authority, legal rational authority, and authority based on the "Wille der Beherrschten" are stable forms, charismatic authority is a "revolutionary force." Hence I begin the discussion with a brief review of the type of domination with traditional authority (Fig. 2).

\section{Traditional authority}

Let us begin with Weber's mature definition of traditional authority:

1) "Legitimacy is claimed for and believed in by virtue of the sanctity of age-old rules ..." (p. 226).

2) "The masters are designated according to traditional rule and are obeyed because of their "Eigenwürde" (traditional status)" (p. 226).

3) "This ... rule is ... primarily based on personal loyalty" (p. 227).

4) "The person exercising authority is not a superior, but a "personal master" (p. 227).

5) "Obedience is owed not to enacted rules, but to the person ..." (p. 227) (emphases are mine).

\footnotetext{
$\overline{{ }^{11} \text { All citations are from Weber } 1978 .}$
} 


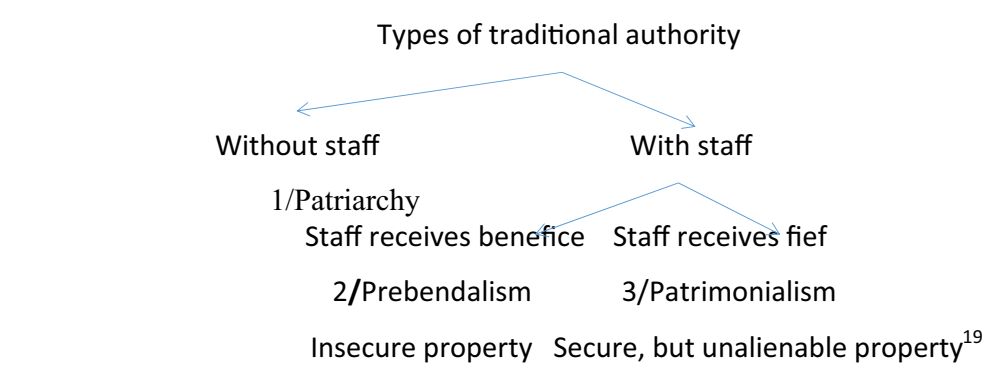

Fig. 2 Types of traditional authority

This seems to be clear enough as an attempt to describe "pre-modern" or "traditional" societies. Weber goes a great deal further and characterizes various types/phasesgiven his dedication to "developmentalism." I try to avoid terms like "stages" in discussing traditional authority.

\section{Charismatic authority}

Not much remains to be said about the second, transitional form of authority: charismatic domination. Its nature is straight forward and it is quite obvious that in some form or degree the charismatic domination concept is applicable not only to archaic societies, but to the world of the twentieth or twenty-first centuries. Weber's definition is clear:

The term 'charisma' will be applied to a certain quality of an individual personality by virtue of which he is considered extraordinary and treated as endowed with supernatural, superhuman, or at least exceptional powers or qualities. These ... are not accessible to the ordinary person, but regarded as of divine origin or as exemplary ... (p. 241) (emphases are mine).

People who subject themselves to charismatic authority consider that person "extraordinary" (almost superhuman, or divine), so charisma is not an innate characteristic of individuals, but it is attributed to them by the followers. But why would they do this? Why would they consider another ordinary person as extraordinary, divine, or exemplary? Weber has a good answer. People "create" charismatic leaders in times of great transformation and crises, when there is a great need for a leader who can deliver miracles and resolve the problems that look almost unresolvable. A Charismatic leader offers hope for the hopeless, promises paradise on Earth. And when they cannot deliver? They lose their charisma:

"If proof and success elude the leader for long ... it is likely that his charismatic authority will disappear" (p. 242) (emphases are mine).

"[The charismatic leader gains and retains his authority] ... solely by proving his powers in practice. He must work miracles... If the people 
withdraw their recognition, the master becomes a mere private person ..." (pp. 1114-1115).

No wonder, charisma is the "revolutionary force":

"In traditionalist periods, charisma is the great revolutionary force ..." (p. 245).

"[B]ureaucratic rationalization, too, often has been a major revolutionary force.... But it revolutionizes with technical means ... "from without" ... Charismatic belief revolutionizes men 'from within' ..." (pp. 1116).

"In pre-rationalistic periods, tradition and charisma between them have almost exhausted the whole of orientation of action" (p. 245). ${ }^{12}$

Charisma hence is in the "eye of the beholder," not a characteristic of the person who is regarded to be charismatic. The term is borrowed from theology ${ }^{13}$ and indeed the "pure types" of charismatic leaders are the founders of great religious movements. Nevertheless there are leaders who strive for and acquire the status of being "charismatic" even in modernity or even under legal-rational authority. Weber considered exceptional individuals in sciences or art to be "charismatic." The question whether they carry "real charisma" or they are pseudo charismatic leaders or they just carry "fake" charisma is debated.. ${ }^{14}$ I take an eclectic position here-Weber's theory of charisma is an ideal type; it does not actually exist in pure form therefore it is reasonable to look for signs of charisma in non-traditional settings as well.

It should be crystal clear: charisma is the type of domination that is transitory; basically it is between one of the forms of traditional authority and another form of traditional authority. Hence it is hard or impossible to pass charisma on from one leader to the next. Arguably one exception is the Roman Catholic Church, but transmission of charisma is rather difficult even in the Church. When one charismatic leader lost his or her charisma or the leader passed away, it is likely that a certain kind of traditional authority will replace that leader. On rare occasions charismatic authority may be turned into legal-rational authority.

\section{Legal-rational authority}

At first glance it appears to be simple and clear what legal-rational domination is and only as we dig deeper do we see that it is a little more complicated.

\footnotetext{
${ }^{12}$ All citations from Weber 1978 .

13 The term was borrowed by Weber from Rudolph Sohm, and from his two volume book on Kirchenrecht, (1982).

${ }^{14}$ There is a large literature on this subject. Edward Shills in his (1965) "Charisma, Order and Status" takes off from Weber and tries to adopt it as a broader concept to be applicable to modernity — one may say even to the mundane word; others took a different direction and suggested in modernity charisma can be abused, faked, as, for example, by what Hitler or Stalin did, or it can be abused for commercial purposes, see Bensman and Givant 1975; more recently Costa Pinto et al. 2007
} 
So how is "obedience" attained under this form?

i. "... person in authority, the "superior," is himself subject to an impersonal order ... ii. ... the person who obeys authority ... obeys only the law ...

iii. ... members do not owe obedience to [superior] as an individual, but to the impersonal order ..." (pp. 217-128) (all emphases are mine). ${ }^{15}$

What is clear that obedience is not due to a personal master but to pre-established laws and rules and the person in authority is subject to the same laws and rules as anyone else. Hence it is legal rather than personal authority. What makes it rational? The fact that it allows rational calculation: the rules have to be pre-established, they cannot change at the discretion of the person in authority and it would follow that legislation can never be retroactive (that would make rational calculation impossible).

Rational calculation is critical for Weber: he goes on at great length to explain why traditional or charismatic authority is inconsistent with modern market capitalism. So traditional authority is not conducive to capitalist development, because:

"[T]he general character of the administrative practices [of traditional authority] ... restrict the development of rational economic activity ... [in the following ways]:

1) Traditionalism places ... obstacles in the way of formally rational regulations, which can depended upon to remain stable and hence calculable ...

2) A staff ... with formal technical training ... is typically absent.

3) There is a wide scope for actual arbitrariness ...

4) [It had] an inherent tendency to regulate economic activity in terms of utilitarian, welfare or absolute value" (pp. 239-240) (emphasis is mine).

Charismatic authority is not conducive to capitalist development either. It is actually "anti-economic force":

Since it is 'extraordinary,' charismatic authority is sharply opposed to rational and particularly bureaucratic authority... Bureaucratic authority is ... rational ... [by] being bound to intellectually analyzable rules; while charismatic authority is specifically irrational in the sense of being foreign to all rules" (p. 244)... [C]harismatic want-satisfaction is a typical anti-economic force ... [it constitutes] an irregular, unsystematic acquisitive act (p. 245) (all emphases are mine).

Hence the only form of domination what is consistent with the requirement of market capitalism is legal-rational authority. It actually could be called a system of "liberalism."But what is the relationship between liberalism and democracy? Weber was called by Mommsen a "liberal in despair." He does not have a clear answer. What matters is that this is a system of rule of law and regulations, which apply equally to all members including the persons in authority. But where do the laws or rules come from? Weber as late as in 1920 does not have a definite answer to this question:

"Legal authority rests on the acceptance of the validity of the following ... ideas:

1. .... norms [laws] may be established by agreement or by imposition, on grounds of expediency or value rationality or both ...

$\overline{{ }^{15} \text { All citations are from Weber } 1978 .}$ 
2. ... law ... [is] ... a consistent system of abstract rules which ... [was] ... intentionally established ..." (p. 217) ${ }^{16}$ (all emphases are mine).

Hence rules or laws can be established by "imposition" or they can be attained by agreement, though Weber is silent with regard to by whom and how such an agreement has to be reached.

To conclude: legal-rational authority MAY be a democratic polity or it may not. The question that haunted political science since the seventeenth century, since Hobbes and Locke (namely the question: who is the source of law?) is not addressed in Weber's typology of domination. For him the critical question is: what is the most suitable political system for capitalist development? It has to be liberal, but - by implication - it does not have to be necessarily democratic. Liberal autocratic or authoritarian regimes have a reasonable record in achieving capitalistic aims. Or do they have to turn eventually to democracy? Is the future of China liberal democracy? We can have a strong political commitment to such a project, but as social scientists: we do not know. Some political theorists have argued (contested by others) democracy is by far the best shell of capitalism (as Lenin put it ${ }^{17}$ ), it was actually achieved by the anti-capitalist struggles of the working class, which forced capitalists to political compromises, such as the welfare state and universal suffrage. Whether capitalism needs democracy or not, whether democracy was forced upon capital by labor or it also the most efficient political tool for private gains: Weber is agnostic. But he is certain: there is no capitalist economy without liberalism. This liberalism implies: rule and stability of laws (and inevitably a separation of executive power from legislative power, no matter how legislative bodies are constituted), equality before the law (what requires an independent judiciary) and security of private property rights. Weber is not as specific about these issues as I am now, but this all logically follows from his theory.

\section{The fourth type of domination}

But the question of how liberalism is related to democracy-nevertheless was on Weber's mind and this is why in 1917 in his lecture in Vienna he considers a fourth type of domination. (This is rarely noticed in scholarship on Weber ${ }^{18}$ ). The Neue Freie Press reports on his October 1917 lecture in Vienna this way: "Schließlich ging er [meaning the lecturer, hence Max Weber] zu der Darlegung über, wie die modern Entwicklung der okzidentalen Staatswesen durch das allmähliche Entstehen eines vierten Legitimationsgendankens charakterisiert war, derjenigen Herrschaft, welche wenigstens offiziell ihre eigene Legitimität aus dem Willen der Beherrschten ableitet" (Weber 2005, Band 22-4, p. 755, my emphasis). Wow. What a sentence! Unlike in his theory of legal-rational authority now legitimacy may stem from the "will" of the people. But Weber cannot help: he is a liberal in despair. After all these people are the

\footnotetext{
${ }^{16}$ All citations are from Weber 1978.

${ }^{17}$ Lenin, V.I. [1917'] 1993. State and Revolution, Chapter 1, in V.I. Lenin. Collected Works. Vol. 25 Lenin Institute Archive, pp. 381-492

${ }^{18}$ Edith Hanke mentions this in her Introduction to $M W G$, Vol. 24-4, 2005 (p. 86-87), but without elaborating on it. See also pp. 745-46. I could not find any secondary scholarly literature on this subject.
} 
"Beherrschten" (they are subjected to domination), the resulting system is still a system of "Herrschaft" rather than the realm of freedom and on top of this is "wenigstens offiziell" (at least officially) the ground for the fourth type of legitimacy. To conclude: Weber takes no stand about the question what is the best "shell" for capitalism: liberal autocracy or liberal democracy.

In my reading, the fourth system of legitimation is a somewhat ironic definition of democratic legitimacy (after all this is the will of those "subjected to authority, not the will of "free citizens"-hence this is a kind of foucauldian ironic comment about what "will" can be). Nevertheless this is articulated before the collapse of the German largely illiberal monarchical autocracy and before the Weimar experiment with liberal democracy. Let me also add: Weber speaks about "will of those subordinated to authority" before he can see the illiberal autocracy that will emerge as a result of the communist revolution in Russia, hence on October 1917 he might have hoped that in post-revolutionary Russia and post-imperial Germany liberal "democracy" might emerge.

It is telling though that when in 1919-1920 Weber re-writes his theory of legitimacy the "fourth type of legitimacy" disappears. Given the mess that the November 7, 1917 revolution in Russia produced and chaotic nature of the Weimar Republic, Weber-probably wrongly-expected the solution would come from Charismatic leaders, rather than "Wille der Beherrschten." What a tragic mistake: charismatic leadership led to disasters, while at least after the Second World War in the Euro-Atlantic region the dominant form of domination became "liberal democracy," hence a combination of legal-rational authority with "Wille der Beherrschten." This arguably is not a perfect, but still the best system of governance-to put it as Churchill did-that humankind has invented so far.

\section{Various types of traditional authority}

Let us return to the various types of "traditional authority." This is important for this article. As I pointed out before Weber' distinction among the various types of authority has two purposes: 1/ it aims to offer a typology of social formation over time. In a way it is a substitute for what Marx offered as a history of "modes of production;" $2 /$ but at the same time it can be used also as an analytic tool to dissect the ways domination operates in any social formation, including "modern" societies. While "modern" societies are primarily legal-rational authorities they may maintain some traditional elements. It is rather uncontroversial to suggest that patriarchal authority exists in "modern societies," even under legal-rational authority. Nevertheless the most provocative hypothesis of this article is to claim that other forms of traditional authority, such as prebendalism or patrimonialism may co-exist with a usually deformed system of legal-rational and democratic authority (hence with the "Wille der Beherschten").

Now let me turn to the four "pure" types of traditional authority: patriarchy, Sultanism, prebendalism, and patrimonialism. Then I offer a hypothesis as to how these types can be applicable to the analysis of contemporary societies. 


\section{Types of traditional authority}

\section{1/ Patriarchy}

The concept of patriarchy is fairly simple:

[Patriarchalism is] " ... the most elementary form of traditional domination where the master has no personal administrative staff." 19

"... The decisive characteristic [of Patriarchalism] is the belief of the members that domination, even though it is an inherent traditional right of the master, must definitely be exercised as a joint right ... of all members. Hence the master is still largely dependent on the willingness of the members to comply with his orders.... Therefore the members (Genossen) are not yet really subjects (Untertanen).,20

This sounds like a good description of tribal societies or, incidentally, the families we happened to live in. And indeed he elaborates it further to make sure it is clear enough the elementary form of patriarchy can be understood as "domestic authority":

"[Under] ... elementary Patriarchalism...the patriarch's authority carries strict obligations to obedience only within his own household... [I]t has only exemplary effect ... or must resort to advice or similar means of influence." 21 This is a sort of "domestic authority (my emphasis) ... [Taking its point of departure from] ... the belief in authority [that] is based on personal relations that are perceived as natural. This belief is rooted in filial piety.... The woman is dependent because of the normal superiority ... of the male... Paternal power ... [is] not primarily based on actual blood relations... [It] is ... power of disposition over property even after the ... recognition that procreation and birth are connected." 22

Patriarchy is not merely an "archaic" form from the distant past, the concept - much like almost all other concepts of Weber - is equally applicable for historical analysis or the analysis of contemporary institutional arrangements.

The other forms of traditional authority operate with a staff. He distinguishes three types of traditional domination with staff. His terminology can be somewhat confusing (especially his uses of the term "patrimonialism," which often means all three types, by distinguishing primary patrimonialism from patrimonial state and the prebendal form of patrimonialism based on benefices, rather than fief. Let me offer the following simplification of Weber's complex analysis of the

\footnotetext{
${ }^{19}$ Max Weber, Economy and Society, 1978, p.231.

${ }^{20}$ Max Weber, Economy and Society, 1978, p.231.

${ }^{21}$ Max Weber, Economy and Society, 1978, p. 231.

${ }^{22}$ Max Weber, Economy and Society, 1978, p. 1007.
} 
three forms of traditional domination. I hope this will bring some clarity in the conceptualization:

\section{2/ Sultanism (a pure case of prebendalism)}

In some cases the members of administrative staff "are purely personal instruments of the master... [When authority] operates primarily on the basis of discretion [of the ruler], it will be called Sultanism.... Sometimes it appears that Sultanism is completely unrestrained by tradition, but this is never in fact the case. The non-traditional element is not, however, rationalized in impersonal terms, but consists in an extreme development of the ruler's discretion." ${ }^{23}$ Under this system the staff possesses the means of administration at the grace of the master and has no security of property rights. Property is not inherited, cannot be alienated, and can be reallocated at any moment at the unilateral decision of the ruler.

Prebendalism is narrowly defined. Under prebendalism the staff appropriates the means of administration of material property only partially. The staff (vassals) receive benefices:

"We shall speak of benefices insofar as the forms of maintenance ... are always newly granted in a traditional fashion ... they can be appropriated by the individual, although not in hereditary fashion.... When an administrative staff is ... supported ... in this form, we shall speak of prebendalism" 24 (my emphases).

While Sultanism offers no security whatsoever, under prebendalism the incumbent of the office can expect to remain in office and retain property as long as he or she assures the master of loyalty and offers valuable services to the master.

\section{3/ Patrimonialism ("feudalism," vassal compensated by fief)}

"Under patrimonial authority ... the administrative staff appropriates particular powers.... Domination of estate type thus involves (i) ... limitation of the lord's discretion in selecting his administrative staff and (ii) ... often ... appropriation by ... staff of $\alpha$ ) the positions ... $\beta$ ) the material means of administration ... $\gamma$ ) the governing power." 25

How the "material means of administration" are appropriated is crucial. Under patrimonial rule narrowly defined, the staff is rewarded by "fief": "[T] he fief is the vassal's personal property for the duration of the feudatory relationship, however, it remains inalienable, since it is intended to preserve the vassal's service capacity." 26 The property that has been granted as "fief" typically can even be inherited; hence patrimonialism with fief offers quite secure property rights (and also security of office). In patrimonialism, both office and property is relatively secure, though the rights of

\footnotetext{
${ }^{23}$ Max Weber, Economy and Society, 1978, p. 231-232. See, for contemporary applications, Chehabi and Linz 1998.

${ }^{24}$ Max Weber, Economy and Society, 1978, p. 235.

${ }^{25}$ Max Weber, Economy and Society, 1978, p.232

${ }^{26}$ Max Weber, Economy and Society, 1978, p.1074
} 
disposal with property by comparison to private property are still limited. Property is usually inalienable; it usually cannot even be mortgaged. It is only given in order to preserve the vassal's capacity to serve.

Historically speaking Sultanism was the form of domination characteristic of the Ottoman Empire. The best approximation of prebendalism in the modern Western world is the Russian service nobility (or Pomeshchiki). The ideal type of patrimonialism is West European feudalism. In Russia, boyars owned property and office in a patrimonial way and they were turned into a service nobility after centuries of struggle by Czars from Ivan the Terrible to Peter the Great. In the following sections, I demonstrate the applicability of the concepts of patrimonialism and prebendalism to post-communist capitalisms.

\section{Types of legitimation under communism and post-communism}

My main aim now is to pose the question: were communist and are post-communist social orders legitimate and, if so, what is the foundation of their legitimacy?

1/ Can one ever call a communist regime legitimate? If so what kind of legitimation regimes describes such communist rule?

I start this with a brief reference to the question: were communist societies' legitimate orders at all? From the point of view of liberal democracy, it would be easy to dismiss communist societies as "illegitimate," but such a position could be hardly attributed to Weber. If we can find instances of communist social order where there is sufficient "voluntary compliance" by the "Beherrschten," Weber would not hesitate to see that order as legitimate and will ask the question what is the foundation of this legitimacy.

In some communist regimes there was not much "voluntary compliance" and order was maintained by systematic coercion. The most extreme example being Cambodia under Pol Pot (though Pol Pot before he became the supreme leader of Cambodia was seen by many as a charismatic figure, see David Chandler 1999) and arguably certain epochs of Stalinism and Maoism were illegitimate, despotic.

But there are long epochs of communism when order was maintained without coercion, where some kind of communist Herrschaft was established. But what kind of Herrschaft? Commentators gave various answers. Some communist leaders at least at certain points in time established a charismatic order (most eminent example would be Fidel Castro, but arguably Lenin and following him for certain epochs even figures such as Stalin could establish themselves as charismatic leaders. The same can be argued for Mao). Whether that was real charisma or just pseudo-charisma can be debated (Bensman and Givant 1975). Some described communism as traditional (Heller et al. 1983) or neo-traditional authority (Andrew Walder 1988), Fehér and Rigby (1992) coined the intriguing term "goal rational authority."

All these theories offer insights and are useful tools to explore empirically various cases at various points in the history of communist societies. Arguably some communist orders had a strong charismatic appeal. The propaganda machine, the "personality cult" obviously was important in manufacturing such charisma, in generating 
enthusiasm and dedication to the leaders who promised to deliver "miracles" through "revolutionary change."

As the leaders failed to deliver miracles or passed away, the system faced the difficult task of institutionalizing charisma or passing it on to another leader. Some communist systems degenerated into illegitimate system, using massive, systemic coercion (as arguably happened in Cambodia, or during the mid-1930s in the USSR, possibly during the Great Leap Forward or Cultural Revolution in China). On some occasions successors made a bid for carrying on the charisma of the predecessor. The best example may be Stalin during the 1920s, when he faked a "last will" of Lenin that supposedly appointed Stalin as successor. He put the propaganda machine into operation and created a personality cult around himself that did deliver some degree of charisma to the young Stalin. Nevertheless, usually after the passing of the original charismatic leader, communist societies struggled for some other type of legitimacy. In some cases, it is indeed an attempt to create some version of a rather classical traditional authority: such is the establishment of the Kim dynasty in North Korea or an attempt to create some neo-traditional authority, based on elaborate patron-client relationships. In this case, the rulers tried to legitimate the system by claims that the party leadership or the individual leader of the party take better care of things than anybody else could. There were also attempts, and for a while rather successful ones, to claim that communist order - in contrast with the "instrumental rationality, or irrationality of the market" - offers a higher level of legitimacy. The communist system, according to this claim, was based on rationality of the goals rather than rationality of means. Communism in other word is "substantive rationality," compared to market capitalism, which is an inferior type of rationality - it is only formal rationality. Rigby and Fehér formulated it this way originally, but in The Intellectuals on the Road to Class Power we also tried to conceptualize the legitimacy of the post-Stalinist USSR and Central Europe in similar terms. "Rational redistributors" claim legitimacy referring to their monopoly on "teleological knowledge" (Konrad and Szelenyi 1979).

Hence the investigation of the kind of legitimacy (or illegitimacy) required historically specific empirical investigation. Actually existing socialist societies combined various elements of all of Weberian ideal types. In a concluding remark on the subject, let me make a provocative statement. Communism appeared to be the opposite of legal-rational authority, by its own aspiration the essence of the Marxian project was to overcome the instrumental formal rationality of market capitalism, the "anarchy of the market." Nevertheless, there were elements of legal-rational authority in most phases and forms of communisms. Communist societies felt obliged to draft constitutions. Curiously, often they pretended they operated under the "rule of law": they tortured prisoners, in the worse times, to confess to crimes punishable by laws, though everyone knew they never committed those crimes. Unlike the Nazis who usually just shot enemies, or sent them to gas chambers and did not bother with complicated legal procedures Stalinism, even at times when it arguably was illegitimate, created "show trials." The best known was the trial against Bukharin. Unlike the Jesuit inquisitors who probably mostly believed the accused had actually committed crimes and who tortured the prisoners to "find the truth," Stalinist prosecutors typically knew the prisoners were innocent, so they tortured them to confess invented crimes that could "justify" the prisoners being executed, since execution was what the law prescribed for the confessed crime. 
During the despotic rule of Stalin, this was mainly "fake legal-rational authority," people often were murdered without any legal procedure. It is hard to detect any element of legal-rationality, or rule of law under Maoism, especially during the Cultural Revolution. During that time Maoists prosecuted enemies in a way similar to the Nazis. But all communists systems were by definition "illiberal" (hence never genuinely legal-rational). Under post-Stalinist reform communism, the legal-rational component was strengthened, but no communist regime was either liberal or democratic in any meaningful sense of those terms. Those in authority may have been formally elected by some body, but de facto they were appointed as members of the "nomenclature" under the control of the executive, be it the Central Committee, the Politburo, or some lower level party organization. None of these systems subscribed to any of the key principles of liberalism: separation of legislative, executive, and juridical power, and security/ sanctity of individual property rights. But it is sensible to suggest that such "fake" legal-rational authority was complementing legitimation beyond charisma, traditional authority, or goal rationality, especially in the reform communist epoch.

And now we are ready to face the question of legitimacy under post-communist regimes. Typically, though there are some substantial country-by-country variations, the first stage of transition from communism to post-communism was a transition from some sort of traditional/neo-traditional/goal rational authority to legal rational authority combined with the "fourth system of legitimation"- - hence with a system that is legitimated by the "Wille der Beherrschten," hence it was at least to some extent democratic.

\section{2/ Early democracy/liberalism. Legal rational authority in Central Europe (with a patrimonial twist)}

Between 1989 and 1991 in most of the formerly socialist countries of Central Europe and in some of the countries of the former USSR, in the Baltic States, and even in Russia, desperate efforts were made to turn these states into liberal democracies with neo-liberal capitalist institutions. Half-hearted reforms were implemented at least during the first few years in war- torn Yugoslavia, Albania, Bulgaria, Romania, Moldova, Ukraine, and the Caucasian republics. Belorussia, the Central Asian former Soviet republics, and certainly the Asian former or still socialist countries, like China and Vietnam are even clearer cases, where no liberal democratic reform took place. But in Central Europe and the Baltic states arguably the dominant form of legitimation was indeed legal rational authority (liberalism) with some form of a democratic polity. The rule of law was accepted, the legislative, executive and juridical powers and the media became reasonably separated from each other. Security of private ownership was acknowledged by the law. Reasonably free multi-party elections were held to constitute the legislative branch.

The most critical challenge all these societies faced in the early years was the conversion of public property into private wealth. According to the neo-liberal doctrine, all problems of transition from a redistributive to market economics will be resolved as soon as identifiable private owners are found for the public assets.

The purpose was to "close the commons" in 500 days (as the Russians tried to do it) or in 5 to 10 years, as the Central European countries attempted. That was difficult or impossible to achieve with purely legal-rational and democratic means. In the democratically elected legislatures, elections were free; there was multi-party competition; but voter turn-out was underwhelming, hence the newly elected governments had a 
somewhat questionable democratic legitimacy. During the electoral campaigns, ideological issues were more often discussed than the crucial question of who will become the private proprietor of assets formerly under public ownership and what will happen with the welfare state. ${ }^{27}$ Hence during the early 1990s liberal democracy, even in the countries that were the closest to the "ideal type," like the Czech Republic and Hungary, there was an inevitable patrimonial component in the system of domination. The privatization legislations - especially those that relied heavily on vouchers - gave a great deal of discretion to the executive branch. In countries that tried to use citizenship vouchers, like in the Czech Republic or Russia, or compensation vouchers, like in Hungary, still needed massively subsidized government credits or grossly undervalued property prices to obtain ownership of large corporations without market-tested creditworthiness. So who was creditworthy was decided by an official in governmental and semi-governmental agencies or by banks - in every case through "personal networks." Even when public property was put up for "auction" and the bidders were international, multi-national firms the buyers needed inside information about the "real value" of the firms up for sale. This again could be obtained by privatization agencies or management of those firms but there was just no way to accomplish this by purely market means. And that deviation from legal-rational authority is what I propose calling a secondary "patrimonial principle" of legitimation.

In the most post-communist liberal-democratic regimes this happened by offering special privileged to management or former knowledgeable and trusted government-party officials. Such a patrimonial element was the weakest in Central Europe. The emergent Central European post-communist capitalism basically could have been described with a legal-rational authority, which operated within a reasonably democratic institution. They were as close to "liberal democracy" as one could expect in societies with making a fast transition from communism to liberal capitalism. Nevertheless many commentators tend to over-idealize the 1990s in Central Europe. In comparison with communism, of course, there was a great leap forward to separation of powers, freedom of the media, the "fourth branch of power," and recognition of the legitimacy of private ownership. In most countries there were reasonably free, multi-party elections. The most vulnerable component of this liberal-democracy was the legitimacy of private ownership and the usually miserable voter turnout at elections. The notions of "theft," and "corruption" were attached to the emergent new private property of the nomenclature-bourgeoisie from day one. Hence private ownership was not as legitimate as one would have hoped. Bálint Magyar coined the term "mafia-state" much later (Magyar 2013), but many ordinary people in Central Europe thought about their new rich as Mafiosi anyway from the very early days of the transition. The separation of power, especially the independence of public media from the government, was also challenged from day one. With this somewhat skeptical note I do accept the

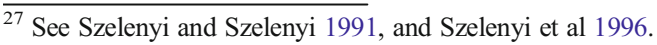


fundamentally legal-rational authority and democratic nature of most Central European countries.

3/ Patrimonialism in Russia during the first decade of transition (with some elements of legal-rational authority)

Russia started to diverge from this trajectory very early on. Already in 1998 (Eyal et al 1998), I called Russia "capitalism from above," a sort of patrimonial order. There may be many reasons for this divergence. Russia has long historical experience with autocratic governments. In addition the new post-communist elites were often recruited from Soviet nomenclature - it was a nomenclature-bourgeoisie. Yeltsin clashed with legal-rational-authority and democratic policy early on. His stated aim was to establish capitalism in Russia in 500 days and the mechanism to achieve this was supposed to be voucher privatization, namely to give a fair share of Russia's "commons" in "vouchers" to every citizen and create millions of owners rather than a few millionaires. But this did not work. Ordinary Russians of course did not know what to do with their vouchers. They were starving, so they sold their vouchers under value to investors/speculators who used them in privatization. What happened next was a classic case of patrimonialism. Yeltsin, the new "czar" had to decide who among the bidders, all with little capital and no credit rating, would acquire the property. He often relied on the advice is his beloved daughter, Tatyana, and she picked the "best people" for the "job." Yeltsin in this way appointed the new grand bourgeoisie. There were "auctions" where property was transformed from public to private, but the Yeltsin regime grossly manipulated these auctions. With these manipulations Yeltsin and his inner circle made sure the people who were defined as "good people" by Tatyana became the new owners (for a colorful and persuasive description of these practices, see Klebnikov 2000). I call the first decade of Russian transition from communism a patrimonial (with some legal-rational components) regime since property was allocated by the "grace" of the ruler. The executive branch had a great deal of autonomy to decide who the new owners would be. The aim of such patrimonial rule, within the framework of a democratic system, was to create a grand bourgeoisie that could be expected to be reasonably loyal to political powers. When the chips were falling, it did work. In 1996 Yeltsin faced re-election as president and he was running behind Zyuganov, the candidate of the Communist Party. The new grand bourgeoisie, the seven largest financiers with the leadership of Berezovsky rallied behind Yeltsin. They hated his opponent, Zyuganov, even more than Yeltsin and since they controlled the media they played a critical role in Yeltsin's re-election. Incidentally the BIG SEVEN claimed just 5 years after the collapse of the USSR that they owned half of the wealth in Russia!

So I call Russia under Yeltsin a patrimonial system. Yeltsin on a few occasions tried to challenge the powers of the new grand bourgeoisie. He had an intense conflict for instance with Gusinsky, but Yeltsin eventually backed down (for the story, see again Klebnikov 2000). Let me just summarize: Russia under Yeltsin was a patrimonial order (property was allocated by the political ruler, but with relatively secure property rights) with some legal-rational authority. It was 
not quite a liberal system, while private property was defended by law, Yeltsin sent tanks against the legislature, when they went against his will. He operated a somewhat managed democratic system. Elections with stakes were held, but the media was controlled by Yeltsin friendly private owners, so it was hardly a "free media". In contrast most Central -European countries were liberal, legal rational authorities, property was allocated by market mechanism (with some patrimonial management though), with substantial separation of powers. A struggle to bring the media under the control of the executive started very early. This was mostly unsuccessful. Elections were free and to the extent the messy campaign financing law allowed it quite fair, but democracies were not "consolidated." It took a long time for parties which can rotate in power were formed and this process is still under way in every Central European post-communist country.

\section{Putin's revolution: a turn to prebendalism with illiberal managed democracy}

\section{The key characteristics of Putinism}

Putin's raise to power represented a major shift in the system of legitimation in post-communist Russia. By the end of the Yeltsin's years, the new Russian grand bourgeoisie began to "privatize" the state itself; big money wanted political power. For a while Berezovsky was national security adviser to Yeltsin. For Putin, an ambitious, energetic, able, young, former KGB man, this was totally unacceptable. He wanted to bring big money under political control, to put a leash on the new grand bourgeoisie. He put the new rich under a loyalty test: those who pass the test can stay and get richer, those who fail have an option to emigrate to London or Tel Aviv, or end up in jail in Siberia. The smart ones, like Berezovsky or Gusinsky went to Sheremetyevo airport; the overly ambitious ones, like Khodorkovsky ended up in long jail terms in Siberia. Those who gave up political ambitions and swore loyalty to the new "czar" became "serving nobility" (like Abramovich and Deripaska). They could stay on and become even richer. Even the fact that they belonged to the Yeltsin "family" was forgotten.

But what mechanism is used to redistribute property already allocated? I would call it the process of selective criminalization. No enemies are prosecuted on political, on ideological grounds: they all are accused of having committed economic crimes, such as tax evasion or corruption. Khodorkovsky was not jailed since he had political ambitions, but because he was found guilty money laundering.... Since the enclosure of the commons took place so fast and usually in a legal vacuum, virtually everyone who is in the class of the nouveau riche has skeletons in his or her closet. Hence the only question is who controls the prosecuting authority and what skeleton the prosecutor will find in whose closet. This is why I call the system selective criminalization. Those who are found guilty are probably guilty all right, but who is not? The question of who will hold private property was still decided by the political authority, but property rights became less secure. To put it in Weber's terms, "fief" was transformed into "benefices", the boyars of Yeltsin became the Pomeshchiki of Putin. The Russian system of legitimation shifted from patrimonialism to prebendalism. Intriguingly this 
was driven by the apparently democratic nature of policy and the inevitable shift to illiberalism in the system of legitimation.

Even in Putin's Russia, the claim that the system is based on majoritarian rule remains important. The regime needs legitimacy in reasonably free and somewhat fair multi-party elections. Those in positions of authority have to win those elections so they need a constituency that will support them. Big money is an important constituency. But how to create or sustain a loyal big money constituency once all the public property was privatized, all the "commons were enclosed?" Since the property that could be used to create or sustain loyal followers was already allocated during the Yeltsin's years, the only way to keep the system going required that property already allocated be redistributed from the non-loyal ones to those Putin hoped would be loyal.

This cannot be achieved in a liberal, legal-rational system of authority where property right are secure, the powers of the executive are checked by the legislature and judiciary, and the media are free. The redistribution of property from the first generation of owners, from the boyars to the Pomeshchiki and the corresponding softening of property rights, requires a strengthening of executive power. This can only be achieved with the limitations of powers of the judiciary, legislative powers and the reduction of the independence of the media, hence a shift from legal-rational authority to an illiberal system of powers. It is important to notice the irony of this process: the shift to the prebendal system of illiberal order is driven by the pressure on those who rule to legitimate themselves with the majoritarian principle, hence by their desires to win elections, which at least appears to be free and fair.

This democratic process under Putin is substantially "managed." It needs to retain the appearance of multi-party democracy. As Perry Anderson (2007) noted, such an illiberal democracy - my term not Anderson's — requires “opposition” parties. Hence it is conceivable that in Putin's Russia the Communist Party is kept alive by Putin himself. At some point such a management goes "too" far and turns managed democracy into autocracy, if there is a chance that at elections the ruling party could lose power. Putin created his own party, the United Russia, in 2001 that has dominated the legislature, the Duma, ever since. It won a super majority, which enabled the Duma to change even the constitution in 2007. In 2011, however, it received merely $51 \%$ of the votes. Would he continue electoral democracy once he faces loss or would he turn his system into an autocracy, with no elections or a Soviet type of fake elections where he would again win $99 \%$ of the votes?

Re-convergence of Russian and Central European ways: the move away from liberalism, toward manage democracy and prebendalism in Central Europe. Is China heading in this direction?

Arguably the Putin "virus" is in the system in most if not in all of the Central European systems. Structurally this stems from the system that operates in a democratic framework, where elections at least have to appear to be competitive and fair. Since the "commons were already enclosed," the only mechanism to "buy" votes is through a redistribution of property already allocated.

Undoubtedly Hungary is the vanguard in "Putinization" of post-communism. The Hungarian Prime Minister, Viktor Orbán, astutely called the system he is trying to establish in Hungary "illiberal democracy." I only would add the term "managed" to this, the best description of the emergent system of legitimation in Hungary is "managed illiberal democracy." 
Much like United Russia in 2007, the Hungarian ruling party, FIDESZ, achieved a supermajority in parliament in 2010. Having the powers to change the constitution, it passed a new constitution. It can change the composition and rights of the constitutional courts - did both — and manage the electoral system for its advantages. For my argument though, the most important development is the "softening" of property rights. Mr. Orbán's party was briefly in government between 1998 and 2002. When they lost in a close electoral competition, Mr. Orbán acknowledged one mistake he made while prime minister: he did not create his own bourgeoisie. This is a mistake one does not make twice. As he won election comfortably in 2010 and 2014, he made an effort to create and maintain a loyal base and its core had to be a propertied bourgeoisie. During the second term of the FIDESZ government (2010-2014), he reallocated petty property rights. A smart move was to create a retail trade monopoly for tobacco shops. Small grocery stores and gas stations made a great deal of their profits from selling tobacco: now only special stores with tobacco licenses had the monopoly of tobacco retail trade. Obtaining such a license did not make anybody into a billionaire but it was a source of nice profit, so one could anticipate that the recipients of such licenses would reward the ruling party by voting for them and they in fact did so in 2014.

After FIDESZ won the 2014 elections in a rather "managed way" with a new qualified, two-thirds majority, it went one step further and is trying now to put big money "on the leash." As the prime minister said, no tree can grow into the skies. Now the attempt is to limit the power of a few oligarchs and replace them with a whole set of smaller and presumably more loyal oligarchs. This is the classical example what I call prebendalism, the making of a class of "serving nobility." In two by-elections in 2015 , FIDESZ lost its two-thirds majority and therefore somewhat limits its illiberal ambitions. The government, for instance, cannot any longer change the electoral rules or the power of the presidency, but it still has absolute majority, so in most legislation the parliament is still just rubber stamping the will of the executive branch.

What we see emerging in post-communism is a novel combination of legal-rational authority operating with a rather or even excessively managed democratic framework combined with some aspects of patrimonialism and, more recently, prebendalism.

Let me be as clear as I can: I am, not writing about any policy error or about a power-grab by one or a few evil individuals. We do see a historically unusual, though not unprecedented, combination of legal-rational authority with some legitimacy claims typically existing under traditional authority. Indeed the managed, illiberal, democratic prebendal states use a substantial dose of "traditionalism" or "conservatism" such as the centrality of religion, patriotism, the traditional family, or the sacredness of life in their ideology. It is illiberal, traditionalistic, conservative, or if you want to put it this way: neo-conservative, or even paleo-conservative. But these practices "inevitably"-if anything is "inevitable" in human history-stem from the accelerated transition from socialism to market capitalism within a democratic framework. Putin and United Russia, Orbán and FIDESZ are reasonably close to being the "pure types" of what I am trying to describe, but the "virus" - no value judgment is meant here to be implied by the term - is in all post-communist democratic societies.

Russian and Hungarian liberal intellectuals tend to demonize Putin or Orbán and these intellectuals do not notice that these politicians have their "twin soul brothers" in virtually all post-communist societies. The Lech and Jarosław Kaczyński in Poland, Vladimir Mećiar and Robert Fico in Slovakia, in some respects Boyko Borisov in 
Bulgaria, Andrej Babiš in the Czech Republic ... and many others represent the same or similar politics and ideology. What the real aim is of Johannis's anti-corruption campaign in Romania is an intriguing question. Klaus Johannis himself was accused of corruption. Is he "cleansing" Romania or is he involved in selective criminalization? In foreign policy they often are very different. Orbán is the most supportive of Putin, even in the Ukrainian crisis; Kaczyński, while a Euro-skeptic like Orbán, is vehemently opposed to Russia.

What is unique about Putin and Orbán is not so much what they are standing for, but who they are: they have a dose of charisma. Whether this is "genuine charisma" or just "fake charisma" can be debated, but it is hard to doubt that, unlike the other traditionalist leaders I mentioned, they can win and re-win election. They both have an enthusiastic and loyal following, though we know their charisma can be withdrawn as soon as the leaders stop delivering "miracles."

The most intriguing, China, seem to be conversing with Putinism as well. President $\mathrm{Xi}$ is making a bid to become a "charismatic leader"; he allows the official media to call him "father Xi." He gives long addresses to scientists and writers about what they should do and his campaign against "corruption" sounds very much like the selective criminalization of the "illiberal democracies" of post-communist European countries. Bo Xilai was a Maoist challenger of the current leadership of the Communist Party. Was he convicted for life imprisonment because he was corrupt, or was it a case of selective criminalization? Former Prime minister Wen's family was reported to own billions of dollars; Bo Xilai was accused of corruption for only a couple of million dollars. The Wen family was not investigated; Bo Xilai got a life sentence. The anti-corruption campaign is suspiciously similar to Putinism. Is China on its way to prebendalism? I do not have enough evidence to tell, but the attack against Bo Xilai and his supporters looks rather similar. Bo Xilai's wife, Gu Kailai, was sentenced also for a life imprisonment for the murder of an English associate (lover? business partner?), Neil Heywood, in a suspiciously short trial, which lasted only for a few days. So who knows what the truth is. But what is certain is that China is moving toward a one-man rule, unknown since the fall of Mao, and the judiciary is being used to catch political enemies. Post-communism from China to Russia to Eastern Europe may be converging on an illiberal prebendal system.

The transition from communism has been guided by the principles of legal-rational authority, what I call liberalism and democracy, what I identify as majoritarian selection of the leaders, Wille der Beherrschten. Given the challenges of fast pace of transition, especially of the conversion of public ownership to private wealth, liberal democracy was not consolidated in most - or any? - of these countries. All of these countries - or most of them - are pregnant with a dose of patrimonialism, prebendalism, and illiberalism, and such potentialities come to fruition as long as their charismatic leaders deliver miracles by providing at least the impression of security and improving welfare.

Open Access This article is distributed under the terms of the Creative Commons Attribution 4.0 International License (http://creativecommons.org/licenses/by/4.0/), which permits unrestricted use, distribution, and reproduction in any medium, provided you give appropriate credit to the original author(s) and the source, provide a link to the Creative Commons license, and indicate if changes were made.

\section{References}

"Russian Journalists: Putin's Regime is Illegitimate" (2012). Columbia University Press, Institute of Modern Russia www.mrussia.org/en/news/213-russian-journaliszs-putins-regime-is-illegitimate. 
Anderson, P. (2007). "Russia's managed democracy”, London Review of Books, No. 2, 2-12.

Bálint, M. (2013). A magyar polip. A poszt-kommunista maffia állam. [The Hungarian Octopus. The postcommunist mafia state). Budapest: Noran Libro.

Bensman, J., \& Givant, M. (1975). Charisma and modernity: the use and abuse of the concept. Social Research, 42(4), 570-614.

Chandler, D. (1999). Brother number one. Boulder: Westview Press.

Chehabi, H. E., \& Linz, J. (1998). Sultanistic regimes. Baltimore: The Johns Hopkins University Press.

Ciobanu, M. (2010). Communist regimes, legitimacy and transition to democracy in Eastern Europe. Nationalities Papers, 38(1), 3-21.

Costa Pinto, A., Eatwell, R., \& Larson, S. U. (Eds.). (2007). Charisma and fascism in interwar Europe. New York: Routledge.

Eyal, G., Szelenyi, I., \& Townsley, E. (1998). Making Capitalism without Capitalists. London: Verso.

Gerth, H. H., \& Wright Mills, C. (1946). From Max Weber: Essays in sociology. New York: Oxford University Press.

Heller, A., Fehér, F., \& Markus, G. (1983). Dictatorship over needs. London: Palgrave Macmillan.

Klebnikov, P. (2000). Godfather of the Kremlin. New York: Harcourt.

Konrad, G., \& Szelenyi, I. (1979). The intellectuals on the road to class power. New York: Harcourt, Brace and Jovanovich.

Kormai, J. (2014).’Fenyegető veszélyek” (Threatening Dangers), Élet és Irodalom, May 23.

Lenin, V.I. [1917'] (1993). State and revolution, chapter 1, in V.I, Lenin. Collected Works. vol. 25 Moscow: Lenin Institute Archive. 381-492.

Mommsen, W. (1974). The age of bureaucracy. Oxford: Blackwell Publishers.

Ossinovski, J. (2010). Legitimacy of political power in Putin's Russia. London: London School of Economics, MSc dissertation.

Rigby, T. H., \& Fehér, F. (Eds.). (1992). Political legitimacy and communist states. New York: S. Martin Press. Roth, G., \& Schluchter, W. (1979). Max Weber's vision of history. Berkeley: University of California Press. Schluchter, W. (1981). The rise of Western rationalism. Berkeley: University of California Press.

Shils, E. (1965). Charisma, order and status. American Sociological Review, 30(2), 199-213.

Sohm, R. (1892). Kirchenrecht. Leipzig: Ducker und Humbolt.

Szelenyi, I, and Szelenyi, S. (1991). "The vacuum in Hungarian Politics”, New Left Review, May-June: 121128.

Szelenyi, I., Szelenyi, S., \& Poster, W. R. (1996). Interests and symbols in post-communist political culture: the case of Hungary. American Sociological Review, 61(3), 466-477.

Walder, A. (1988). Communist neo-traditionalism. Berkeley: University of California Press.

Weber, M. (1947). The theory of social and economic organization. From Wirtschaft und Gesellschaft translated by Talcott Parsons. New York: Then Free Press.

Weber, M. (1978). Economy and society. Berkeley: University of California Press.

Weber, M. (1999). Max Weber Gesamtausgabe. Band 22-5. Tübingen: Mohr und Siebeck.

Weber, M. (2005). Max Weber Gesamtausgabe. Band 22-4. Tübingen: Mohr und Siebeck.

Weber, M. (2013). Max Weber Gesamtausgabe. Band 23. Tübingen: Mohr und Siebeck.

Zakaria, F. (1997). The rise of illiberal democracy. Foreign Affairs, 76(8), 22-43.

Iván Szelenyi is the William Graham Sumner Emeritus Professor of Sociology and Political Science at Yale University and the Max Weber Emeritus Professor of Social Sciences at NYUAD. He is a Fellow of American Academy of Arts and Sciences and an ordinary member of the Hungarian Academy of Sciences, as well as a Senior Editor of Theory and Society. 